\title{
A proposed groundwater management framework for municipalities in South Africa
}

\author{
K Riemann*, N Chimboza and M Fubesi \\ Umvoto Africa (Pty) Ltd, PO Box 61, Muizenberg, Cape Town, Western Cape, South Africa
}

\begin{abstract}
Groundwater is not being perceived as an important water resource and therefore has been given limited attention in South Africa. This is reflected in general statistics showing that only $13 \%$ of the nation's total water supply originates from groundwater. In contrast, most towns in arid areas depend on groundwater either as a sole supply or as an essential supply for drought management. The perception remains that groundwater is not a sustainable resource for bulk domestic supply and cannot be managed properly. Despite this, a growing number of municipalities utilise groundwater on a regular basis, and provide examples of successful management of this resource. Various guidelines for groundwater management in South Africa have been developed. These are valuable sources of information in terms of requirements and steps to protect and manage aquifers. However, an overarching groundwater management framework was still lacking. Hence, the Water Research Commission (WRC) has commissioned a project to develop a Groundwater Management Framework that incorporates all aspects of groundwater management at municipal level. The proposed Groundwater Management Framework aims to improve on the management of groundwater resources by equipping the responsible authorities with the required tools and capacity. This goes beyond data collection and monitoring, and requires human and capital resources. The framework includes a detailed description of the different functions and the relevant responsibilities, the required skills, the optimal position within the municipal structure and required communication lines. Hence, the assigned responsibilities and available tools to achieve sustainable groundwater management reflect the local level of water institutions, i.e. Water Services Authority (WSA), Water Services Provider (WSP) and Water User Associations (WUAs). However, the principles of the framework can be applied at all levels and all scales. It is recommended that this framework be rolled out and promoted at the local government level, in combination with requisite skills development at operational level, and training of municipal officials, as well as providing incentives for successful implementation and integration of groundwater management in municipal planning.
\end{abstract}

Keywords: groundwater management, guideline, aquifer protection, aquifer utilisation, monitoring

\section{Management}

'Management is the art of getting things done through people', according to Mary Parker Follett (1868-1933) (Barrett, 2003 p. 51). Management in all business and human organisation activity is simply the act of getting people together to accomplish desired goals and objectives. The principles of management have been expanded and applied to other forms of organisations, specific areas within a business (e.g. human resource management, risk management, operations management), personal behaviour (e.g. self management, time management) and natural resources (e.g. land management, water resource management).

Management operates through various functions. The business management schools normally distinguish between 4 and 7 basic management functions, of which the 4 most important are planning, organising, leading/motivating, and controlling:

- Planning: Deciding what needs to happen in the future (today, next week, next month, next year, over the next 5 years, etc.) and generating plans for action

- Organising (implementation): Making optimum use of the resources required to enable plans to be carried out successfully

This paper was originally presented at the International Conference on Groundwater: Our Source of Security in an Uncertain Future, Pretoria, 19-21 September 2011.

* To whom all correspondence should be addressed.

㟨 +27 21 709-6700; fax: +27 86 524-0001; e-mail: kornelius@umvoto.com
- Leading/directing: Determining what needs to be done in a situation and getting people to do it

- Controlling/monitoring: Checking progress against plans, which may need modification based on feedback

These 4 management functions are the building blocks for all types of management. They form an ongoing cycle of management, as the results of 'Controlling' might require changes of the objectives ('Planning'), changes in organisational structure ('Organising'), changes in personnel ('Staffing') or changes in interpersonal relationships ('Directing'), as indicated in Fig. 1. The main elements of the management functions and the responsibilities within the municipal structure are shown in Table 1.

\section{Context of the groundwater management framework}

The Groundwater Management Framework (GMF) is the outcome of a WRC-funded project on Groundwater Management Functions (Riemann et al., 2011). The GMF forms part of the Integrated Water Resource Management (IWRM) framework and must be seen in the context of other relevant guidelines and activities, such as catchment management, water conservation and demand management (WC/WDM), waste and wastewater management, water resource planning and management, and delivery of water services.

A detailed review of the national and international guidelines and publications with respect to the legal framework, 


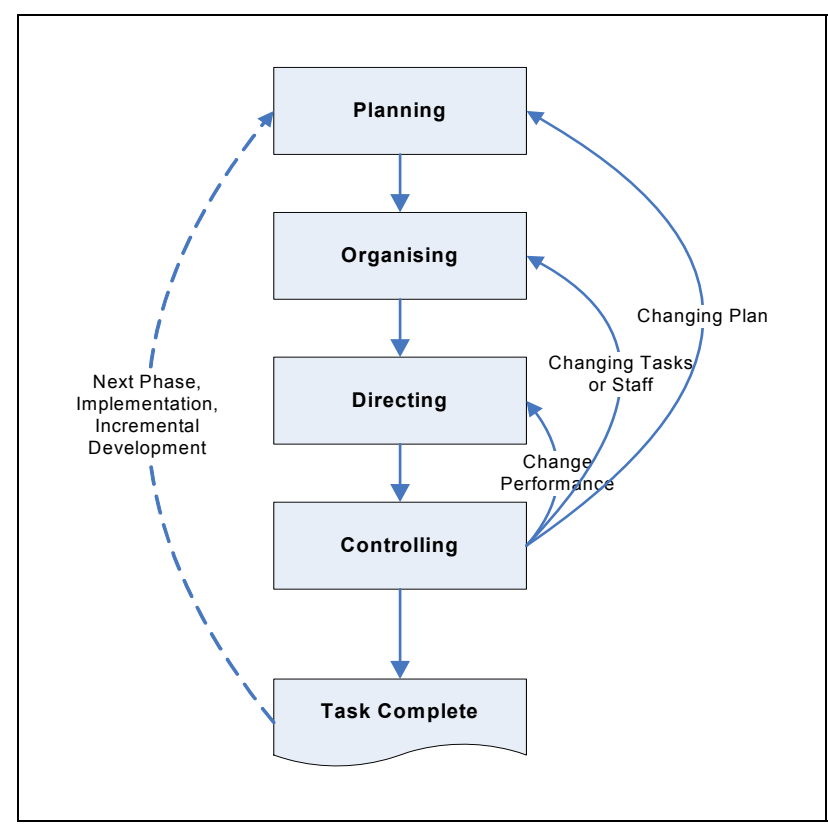

Figure 1

Review and revise cycle of management functions; from planning through organising and directing to controlling and back to planning for the next task completeness of all relevant aspects, feasibility of implementation and functionality was concluded with a gap analysis. It indicated that the following aspects and management functions require particular attention in the development of the

Groundwater Management Framework:

- Definition of 'groundwater management' and all relevant aspects of it

- Definition of the relevant management functions with respect to groundwater management

- Mapping of roles and responsibilities of water institutions for the different groundwater management activities

- Outlining required skills for the different groundwater management activities

- Integrating the various groundwater management guidelines into one document.

\section{Legal framework}

The National Water Act (NWA), Act No. 36 of 1998 (RSA, 1998), provides the legal framework for water resource management. It prescribes the use of the IWRM approach to ensure that all aspects of water resource management are considered. The National Water Act deals with the water resource. That is rivers, streams, dams, lakes and groundwater. It contains rules about the way the water resource (surface and groundwater) is protected, used, developed, conserved, managed and controlled in an integrated manner. This Act states that water is an indivisible national resource for which national government is the custodian. It further outlines the principles of using and managing this resource.

\begin{tabular}{|c|c|c|c|c|c|}
\hline \multicolumn{6}{|c|}{$\begin{array}{c}\text { Table } 1 \\
\text { Elements of management functions with corresponding responsibilities in municipal structure }\end{array}$} \\
\hline & Task / Action & Operator & Supervisor & $\begin{array}{l}\text { Technical } \\
\text { Manager }\end{array}$ & \begin{tabular}{c|c} 
Head of \\
Department
\end{tabular} \\
\hline \multirow{3}{*}{ Planning } & Visioning & & & & $\mathrm{R}$ \\
\hline & Define goal & & & & $\mathrm{R}$ \\
\hline & Define objectives & & & & $\mathrm{R}$ \\
\hline \multirow{9}{*}{ Organising } & Allocation of authorities and tasks & & & $\mathrm{R}$ & $\mathrm{A}$ \\
\hline & Preparing budget & & & $\mathrm{R}$ & $\mathrm{A}$ \\
\hline & Terms of Reference & & $\mathrm{S}$ & $\mathrm{R}$ & A \\
\hline & Tender/ contracts & & & $\mathrm{R}$ & $\mathrm{A}$ \\
\hline & Hiring qualified staff & & $\mathrm{S}$ & $\mathrm{R}$ & $\mathrm{A}$ \\
\hline & Training of staff & & $\mathrm{S}$ & $\mathrm{R}$ & $\mathrm{A}$ \\
\hline & Allocating time / staff to tasks & & & $\mathrm{R}$ & $\mathrm{A}$ \\
\hline & Appoint external contractor & & & $\mathrm{R}$ & $\mathrm{A}$ \\
\hline & Performance indicators & & & $\mathrm{R}$ & $\mathrm{A}$ \\
\hline \multirow{4}{*}{ Directing } & Tasking & & $\mathrm{S}$ & $\mathrm{R}$ & $\mathrm{A}$ \\
\hline & Motivating & & $\mathrm{S}$ & $\mathrm{R}$ & $\mathrm{A}$ \\
\hline & Supervision & & $\mathrm{S}$ & $\mathrm{R}$ & $\mathrm{A}$ \\
\hline & Revision of tasks & & $\mathrm{S}$ & $\mathrm{R}$ & $\mathrm{A}$ \\
\hline \multirow{6}{*}{ Controlling } & Data collection & $\mathrm{S}$ & $\mathrm{R}$ & $\mathrm{A}$ & \\
\hline & Monitoring & $\mathrm{S}$ & $\mathrm{R}$ & $\mathrm{A}$ & \\
\hline & Data analysis & $\mathrm{S}$ & $\mathrm{R}$ & A & \\
\hline & Review & & & $\mathrm{R}$ & $\mathrm{A}$ \\
\hline & Approval of revision $=$ back to $\mathrm{P}$ or $\mathrm{O}$ & & & $\mathrm{R}$ & $\mathrm{A}$ \\
\hline & Staff performance assessment & & & $\mathrm{R}$ & $\mathrm{A}$ \\
\hline \multicolumn{6}{|c|}{$\begin{array}{ll}R & \text { Responsible - This role conducts the actual work/owns the problem. There should be only one } R . \\
A & \text { Accountable - This role approves the completed work and is held fully accountable for it. }\end{array}$} \\
\hline \multicolumn{6}{|c|}{$S$ Supportive - This role provides additional resources to conduct the work or plays a supportive role in implementatio } \\
\hline
\end{tabular}


With the promulgation of the National Water Act in 1998, groundwater lost its previous status of private water and became public water. This has enormous implications for all users and important benefits for municipalities as public users. It is now possible for municipalities to exploit groundwater resources even where these can only or best be accessed on private land.

The Water Services Act, Act No. 108 of 1997 (RSA, 1998), deals mainly with water services or potable (drinkable) water and sanitation services supplied by municipalities to households and other municipal water users. It contains rules about how municipalities should provide water-supply and sanitation services. The Act defines the municipal functions of ensuring water services provision and sets out guidelines for WSAs as well as WSPs. The roles and responsibilities of both the WSA and WSP in terms of water resource management are not explicitly stated but can be inferred from their different roles in the provision of water services.

\section{Department of Water Affairs (DWA) guidelines - integrated water resource management}

A number of guidelines for groundwater management have been developed internationally and for the South African context. The most relevant for the purpose of this study are the NORAD Toolkit, 'NORAD-Assisted Programme for Sustainable Development of Groundwater Sources' (DWAF, 2004b); the 'Guidelines for the Monitoring and Management of Ground Water Resources in Rural Water Supply Schemes' (Meyer, 2002) and the 'Guideline for the Assessment, Planning and Management of Groundwater Resources in South Africa' (DWAF, 2008).

Other relevant documents include water-quality management protocols, minimum standards, the Framework for a National Groundwater Strategy (DWAF, 2007a), the Groundwater Strategy 2010 (DWA, 2011), the National Water Resource Strategy (DWAF, 2004c), the 'Guidelines for Catchment Management Strategies Towards Equity, Sustainability and Efficiency' (DWAF, 2007b) and regional groundwater plans, as well as selected national and international articles and publications on groundwater management aspects. More recently, other WRC-funded projects commenced that support the general initiative to assist the local authorities with groundwater development and management.

The DANIDA guideline (DWAF, 2004a) outlines the principles of groundwater management in the context of IWRM. The main authorities involved in groundwater management include the Department of Water Affairs (DWA), catchment management agencies (CMAs) and water user associations (WUAs).

- The DWA is responsible for national legislation and planning; the development of national groundwater resource policy, regulation and monitoring, and provision of support to other water-resource institutions

- The CMAs are responsible for water resource management within their water management area

- The WUAs are responsible for the above functions at a local level, representing individual water users and providing vehicles for public participation.

The 'Guideline for the Assessment, Planning and Management of Groundwater Resources in South Africa' (DWAF, 2008) intends to assist in the sustainable development, protection and management of the groundwater resources, and in achieving the overall goal of integrated water resource management (IWRM) within the Department. Management of groundwater resources relates to the sustainable use and development of these resources. It focuses on the sustainable development of the groundwater resources without compromising resource integrity (quantity and quality of the resource). Management thus involves monitoring quantity and quality over a long-term period and the use of information to determine compliance against set goals and to assess whether the strategic goals of the department are being met.

The guideline describes the management principles at the national, the CMA and the site-specific level. Management of water resources is enabled through water allocation and wateruse authorisation. Management at site-specific level entails, among others, maintenance and control, monitoring and measurement, data management and reporting, auditing and management of impacts. Review of compliance with water-use authorisation conditions is undertaken at the catchment level, as well as managing the cumulative impacts of the various water-user groups on the system. The auditing of compliance with strategic goals and strategic reviews is undertaken at the national level.

These IWRM and groundwater-specific strategies, guidelines and frameworks fit into the overarching proposed Groundwater Management Framework, describing specific aspects of the groundwater management. The following guidelines are considered most relevant and become an integral part of the Groundwater Management Framework:

- NORAD Toolkit (DWAF, 2004b)

- Guideline on Assessment, Planning and Management (DWAF, 2008)

- WIN-SA Guidelines

- DANIDA IWRM Framework

- South African Water Quality Guidelines

- Minimum requirements for waste sites

- IWRM Plan Guideline

\section{Structure of the framework}

The Groundwater Management Framework provides a guideline for optimal incorporation and integration of the management functions in the municipal structure. The Framework is designed to be applicable at local level of responsibilities; i.e. WSA, WSP, WUA. Hence, the assigned responsibilities and available tools to achieve sustainable groundwater management reflect the local level of water institutions. However, the principles of the Framework can be applied at all levels and at all scales.

The current definitions of 'water resource management' and more so 'groundwater management' vary significantly and are not consistent throughout the legal framework and guidelines. For the development of the Groundwater Management Framework, a comprehensive definition of groundwater management has been applied that includes aquifer protection, groundwater-quality management, groundwater remediation, groundwater assessment, groundwater monitoring, well-field planning and design, and well-field operation and maintenance

The different aspects of groundwater management, as defined above, relate to 2 main categories, viz.:

- Aquifer protection

- Aquifer utilisation

In addition, there are 2 overarching and supporting categories that are relevant for successful groundwater management, viz.: 


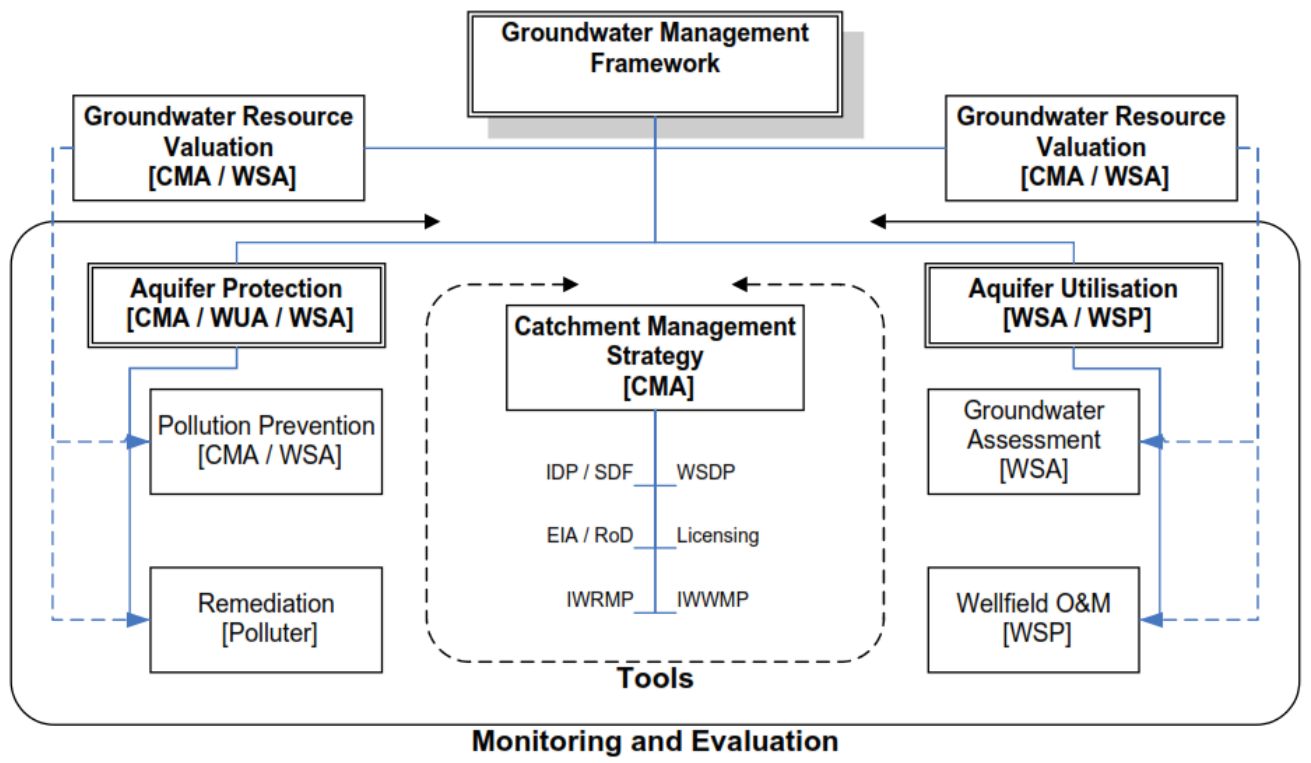

Figure 2

Structure of

Groundwater

Management

Framework with categories 'Aquifer

Protection' and

'Aquifer Utilisation',

their subcategories, overarching functions

of 'Monitoring

and Evaluation'

and 'Groundwater

Resource Valuation'

and main available tools

- Monitoring, data management and evaluation

- Valuation of the groundwater resource

The overall structure of the Groundwater Management Framework is shown in Figure 2. The framework provides the overarching structure, while the existing guidelines (see above) provide further details of required actions and responsibilities. The local authorities have a number of tools and planning instruments at their disposal to implement groundwater management that must be aligned to the Catchment Management Strategy (CMS) of the CMA. These are the Integrated Development Plan (IDP) with their associated Spatial Development Framework (SDF) and Water Services Development Plan (WSDP), required Environmental Impact Assessments (EIA) with their Record of Decision (RoD), licences and permits for water use and discharge, Integrated Water Resource Management Plan (IWRMP) and Integrated Waste and Wastewater Management Plan (IWWMP).

The category of 'Aquifer Protection' includes all activities to protect the aquifer from deterioration in water quality and reduction in aquifer recharge, and to rehabilitate an aquifer with respect to its water quality, irrespective of whether the aquifer is utilised or not. Therefore, the relevant subcategories are pollution prevention and remediation (see Fig. 3). The prevention of aquifer pollution and degradation is achieved at local government level with 2 main tasks, viz. land-use planning and pollution-control measures.

Land-use planning involves the spatial demarcation or zoning of areas for specific use, and the determination of restrictions of land use within these areas. Furthermore, the

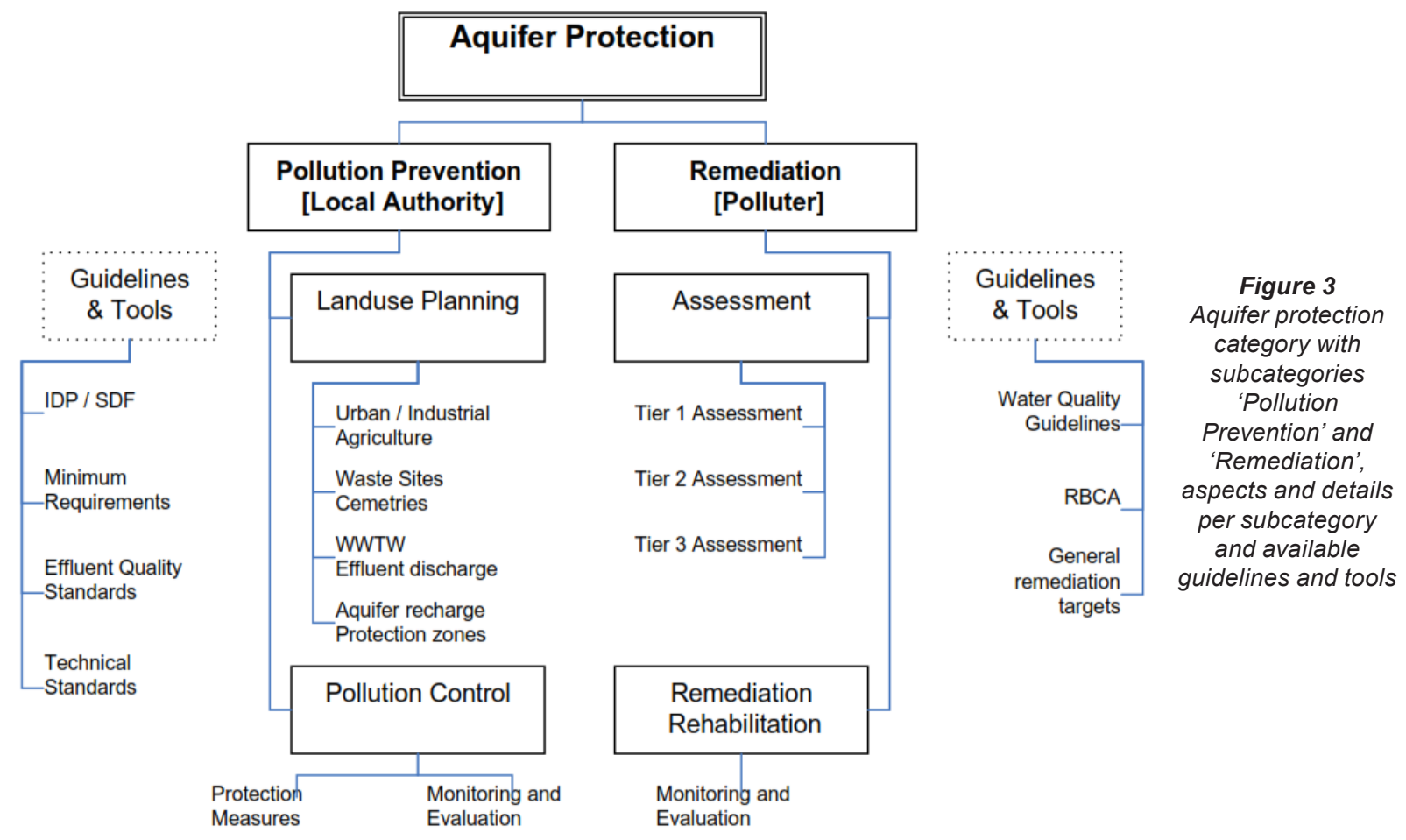

http://dx.doi.org/10.4314/wsa.v38i3.10 


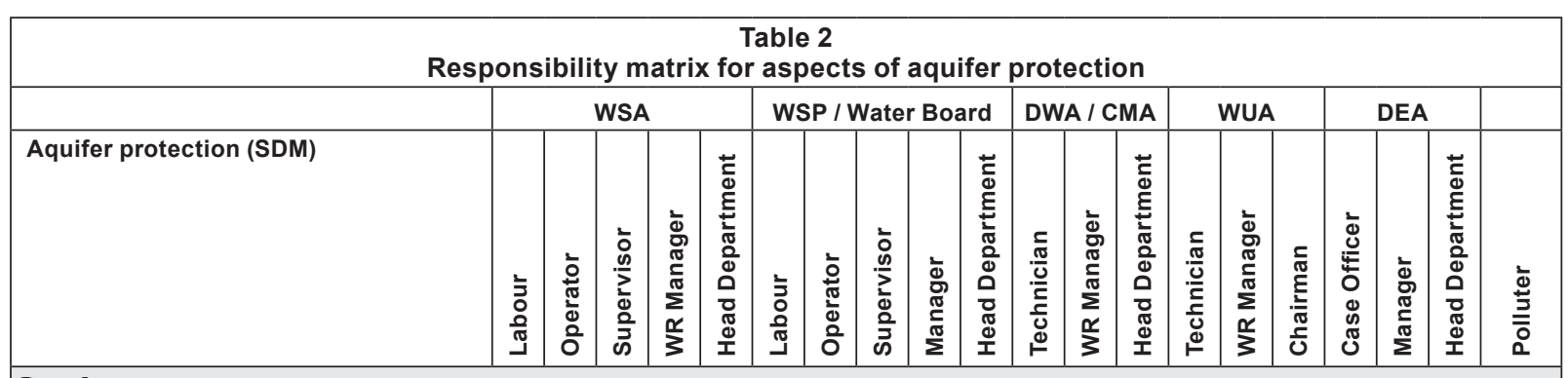

\begin{tabular}{|c|c|c|c|c|c|c|c|c|c|c|c|c|c|c|c|c|c|c|c|c|}
\hline \multicolumn{21}{|l|}{\begin{tabular}{|l} 
Land use \\
\end{tabular}} \\
\hline Catchment Management Strategy & & & & C & & & & & & & & & $\mathrm{R}$ & $\mathrm{A}$ & & $\mathrm{C}$ & $\mathrm{II}$ & & & \\
\hline Development / update of IDP / SDF & & & & $\mathrm{R}$ & A & & & & & & & & I & & & $\mathrm{C}$ & I & & & \\
\hline Land-use planning & & & & $\mathrm{R}$ & $\mathrm{A}$ & & & & & & & & $\mathrm{R}$ & & & $\mathrm{C}$ & I & I & I & \\
\hline Waste management & & & & & & & & & & $\mathrm{R}$ & A & & I & & & $\mathrm{C}$ & I & I & I & \\
\hline Waste water management & & & & $\mathrm{I}$ & & & & & & $\mathrm{R}$ & $\mathrm{A}$ & & I & & & $\mathrm{C}$ & $\mathrm{I}$ & I & I & \\
\hline Effluent quality management & & & & $\mathrm{I}$ & & $\mathrm{S}$ & $\mathrm{I}$ & $\mathrm{R}$ & $\mathrm{A}$ & $\mathrm{I}$ & & & I & & & & & I & $\mathrm{I}$ & \\
\hline \multicolumn{21}{|l|}{ Remediation } \\
\hline Groundwater remediation & & & & $\mathrm{I}$ & & & & & & & & & $\mathrm{C}$ & & & & & I & $\mathrm{I}$ & $\mathrm{R} / \mathrm{A}$ \\
\hline \multicolumn{21}{|l|}{ Monitoring } \\
\hline Groundwater monitoring & $\mathrm{S}$ & $\mathrm{R}$ & A & I & & & & & & & & & I & & $\mathrm{S}$ & $\mathrm{I}$ & I & & & \\
\hline Regional GW monitoring & & & & I & & & & & & & & $\mathrm{R}$ & I & A & $\mathrm{S}$ & I & I & & & \\
\hline GWQ monitoring (Pollution) & & & & $\mathrm{I}$ & & $\mathrm{S}$ & I & $\mathrm{R}$ & $\mathrm{A}$ & $\mathrm{I}$ & & & I & & $\mathrm{S}$ & I & $\mathrm{II}$ & I & I & $\mathrm{R}$ \\
\hline Ecological monitoring & & & & & & & & & & & & $\mathrm{R}$ & I & A & $\mathrm{S}$ & I & I & I & I I & \\
\hline
\end{tabular}

implementation of the zoning and the effectiveness of the zoning and restrictions with respect to water quality and aquifer recharge needs to be monitored and evaluated regularly.

Zoning and development is a component of the Integrated Development Plan (IDP) and must reflect in the municipal Spatial Development Framework (SDF). The management of land use should include the evaluation of zoning, potential restrictions on land use, development and conservation of urban open space and remediation measures, if required.

While land-use planning is concerned with the general potential impact of activities on the groundwater quality and quantity, the element of pollution control involves direct measures to ensure that the potential impact is reduced further and mitigated against.

Remediation is usually the responsibility of the polluter. To develop realistic, cost-effective and site-specific remedial options, it is imperative that the remediation be designed and conducted within the context of an accepted decision-making framework such as Risk-Based Corrective Action (RBCA).

The levels of responsibility and involvement of staff from the relevant institutions at different levels for the different aspects are shown in Table 2.

The category of 'Aquifer Utilisation' includes all activities to ensure that the groundwater use is sustainable and that impacts from the groundwater use are avoided or mitigated (see Fig. 4). The activities can be grouped into groundwater assessment, and well-field operation and maintenance (O\&M).

The development of aquifer schemes and implementation of well-fields should follow a standard project process, which is similar to other infrastructure development. The main elements of this process are the different levels of groundwater assessment from reconnaissance to feasibility studies, option analyses and well-field planning and design.

The feasibility-level planning study is an intensive investigation and optimisation of the most beneficial layout of the scheme under investigation, resulting in the best layout of the scheme and its major dimensions and final specifications, providing sufficient information to enable detailed design of the preferred scheme.

At the end of the feasibility study, an application for a water-use licence in terms of the National Water Act (NWA) (Act No. 36 of 1998) as may be required from the DWA or the CMA and for environmental authorisation in terms of the National Environmental Management Act (NEMA) (Act No. 107 of 1998) should be submitted to the relevant authorities. Although not a legal requirement, it is recommended that the WSA appoint their hydrogeological consultant to undertake the Reserve Determination Study.

The design and implementation of a well-field, as well as the ongoing operation of the well-field is grouped under the 'Well-field O\&M Subcategory', as these are strongly linked in terms of sustainable groundwater management. The management options during the operation need to be considered during the design and construction phase.

Management of groundwater resources relates to the sustainable use and development of these resources. It focuses on the sustainable development of the groundwater resources without compromising resource integrity (quantity and quality). Management thus involves monitoring quantity and quality over a long-term period and the use of this information to determine compliance against set goals and to assess whether the strategic goals of the Department are being met.

Possibly the most important element of groundwater management is day-to-day operation and maintenance (O\&M). A groundwater supply scheme might be as simple as a single borehole with a hand pump, although schemes usually involve more than one borehole, pipe-work, electrical control systems, treatment systems, etc. Operation and maintenance tasks include maintaining infrastructure (cleaning and descaling pipes, replacing worn-out components, cleaning of boreholes, checking the operation of switchgear, etc.) as well as the monitoring of groundwater levels, groundwater quality, water demand, etc., to assist with the ongoing groundwater management 


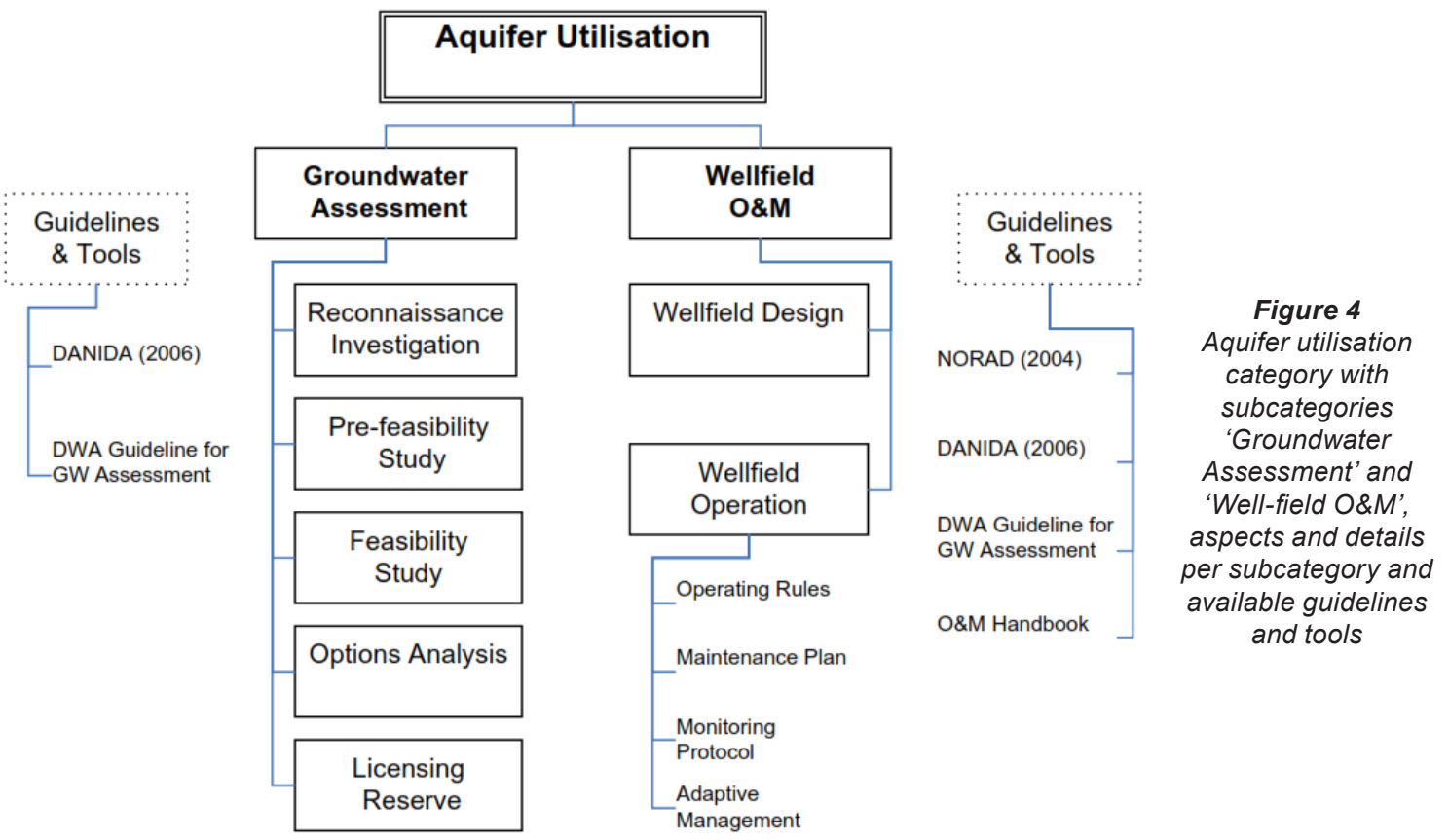

Table 3

\begin{tabular}{|c|c|c|c|c|c|c|c|c|c|c|c|c|c|c|c|c|c|c|c|}
\hline \multicolumn{20}{|c|}{$\begin{array}{c}\text { Table } 3 \\
\text { Responsibility matrix for aspect }\end{array}$} \\
\hline \multirow[b]{2}{*}{ Groundwater development (RDM) } & \multicolumn{5}{|c|}{ WSA } & \multicolumn{5}{|c|}{ WSP / Water Board } & \multicolumn{3}{|c|}{ DWA / CMA } & \multicolumn{3}{|c|}{ WUA } & \multicolumn{3}{|c|}{ DEA } \\
\hline & 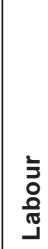 & 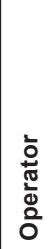 & 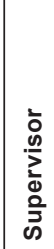 & 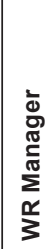 & 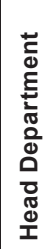 & 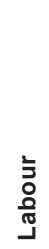 & 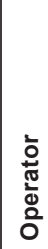 & 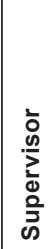 & 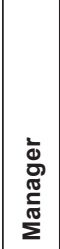 & 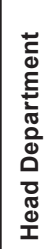 & 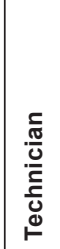 & 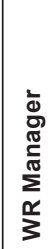 & 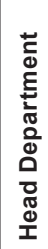 & 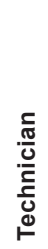 & 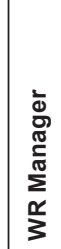 & 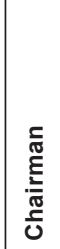 & 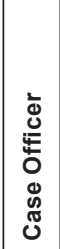 & 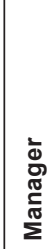 & 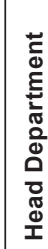 \\
\hline \multicolumn{20}{|l|}{ Groundwater assessment } \\
\hline Reconnaissance study & & & & $\mathrm{R}$ & A & & & & I & I & & C & & & I & I & & & \\
\hline Pre-feasibility study & & & & $\mathrm{R}$ & A & & & & $\mathrm{I}$ & $\mathrm{I}$ & & $\mathrm{C}$ & & & $\mathrm{I}$ & $\mathrm{I}$ & & & \\
\hline Feasibility study & & & & $\mathrm{R}$ & $\mathrm{A}$ & & & & $\mathrm{I}$ & I & & $\mathrm{C}$ & & & I & I & & & \\
\hline Options analysis & & & & $\mathrm{R}$ & A & & & & I & $\mathrm{I}$ & & $\mathrm{C}$ & & & I & I & & & \\
\hline License application & & & & $\mathrm{R}$ & A & & & & C & I & & $\mathrm{C}$ & & & $\mathrm{C}$ & I & & & \\
\hline Reserve determination & & & & $\mathrm{C}$ & $\mathrm{I}$ & & & & $\mathrm{C}$ & $\mathrm{I}$ & $\mathrm{S}$ & $\mathrm{R}$ & $\mathrm{A}$ & & $\mathrm{C}$ & $\mathrm{I}$ & & & \\
\hline EIA / RoD & & & & $\mathrm{C}$ & $\mathrm{I}$ & & & & $\mathrm{C}$ & I & & $\mathrm{C}$ & & & $\mathrm{C}$ & & $\mathrm{R}$ & $\mathrm{C}$ & A \\
\hline Licensing & & & & $\mathrm{C}$ & $\mathrm{I}$ & & & & $\mathrm{C}$ & $\mathrm{I}$ & & $\mathrm{R}$ & A & & $\mathrm{C}$ & $\mathrm{I}$ & & $\mathrm{C}$ & \\
\hline \multicolumn{20}{|l|}{ Well-field O\&M } \\
\hline Well-field planning and design & & & & $\mathrm{I}$ & & & & & $\mathrm{R}$ & $\mathrm{A}$ & & I & & & & & & $\mathrm{I}$ & \\
\hline Well-field development & & & & I & & & & $\mathrm{S}$ & $\mathrm{R}$ & A & & I & & & & & & I & \\
\hline Well-field operation and maintenance & & & & $\mathrm{I}$ & & $\mathrm{S}$ & $\mathrm{R}$ & $\mathrm{C}$ & A & & $\mathrm{S}$ & $\mathrm{I}$ & & $\mathrm{S}$ & & & & I & \\
\hline \multicolumn{20}{|l|}{ Monitoring } \\
\hline Groundwater baseline monitoring & $\mathrm{S}$ & $\mathrm{R}$ & $\mathrm{C}$ & $\mathrm{I}$ & A & & & & & & $\mathrm{S}$ & I & & $\mathrm{S}$ & $\mathrm{I}$ & & & $\mathrm{I}$ & \\
\hline Groundwater compliance monitoring & & & & I & & $\mathrm{S}$ & $\mathrm{R}$ & $\mathrm{C}$ & I & A & & I & & & I & & & I & \\
\hline
\end{tabular}

The levels of responsibility and involvement of staff from the relevant institutions at different levels for the various aspects are shown in Table 3.

All categories and subcategories require data collection and ongoing monitoring. These activities must be structured and coordinated such that the monitoring data can be utilised for their intended purposes.

The economic aspect of sustainable groundwater management is of importance for the local authority. A framework for the valuation of the groundwater resource is provided, which feeds into both categories and their subcategories.

\section{Case studies}

A number of case studies of best practice were carried out to identify success parameters for sustainable groundwater management at local authority level. Common parameters were appropriate technology for groundwater monitoring and management, scientific support from external consultants on request, efficient management structure, committed staff, and adequate funding mechanism.

The proposed Groundwater Management Framework was tested and implemented as a case study in the Overstrand 


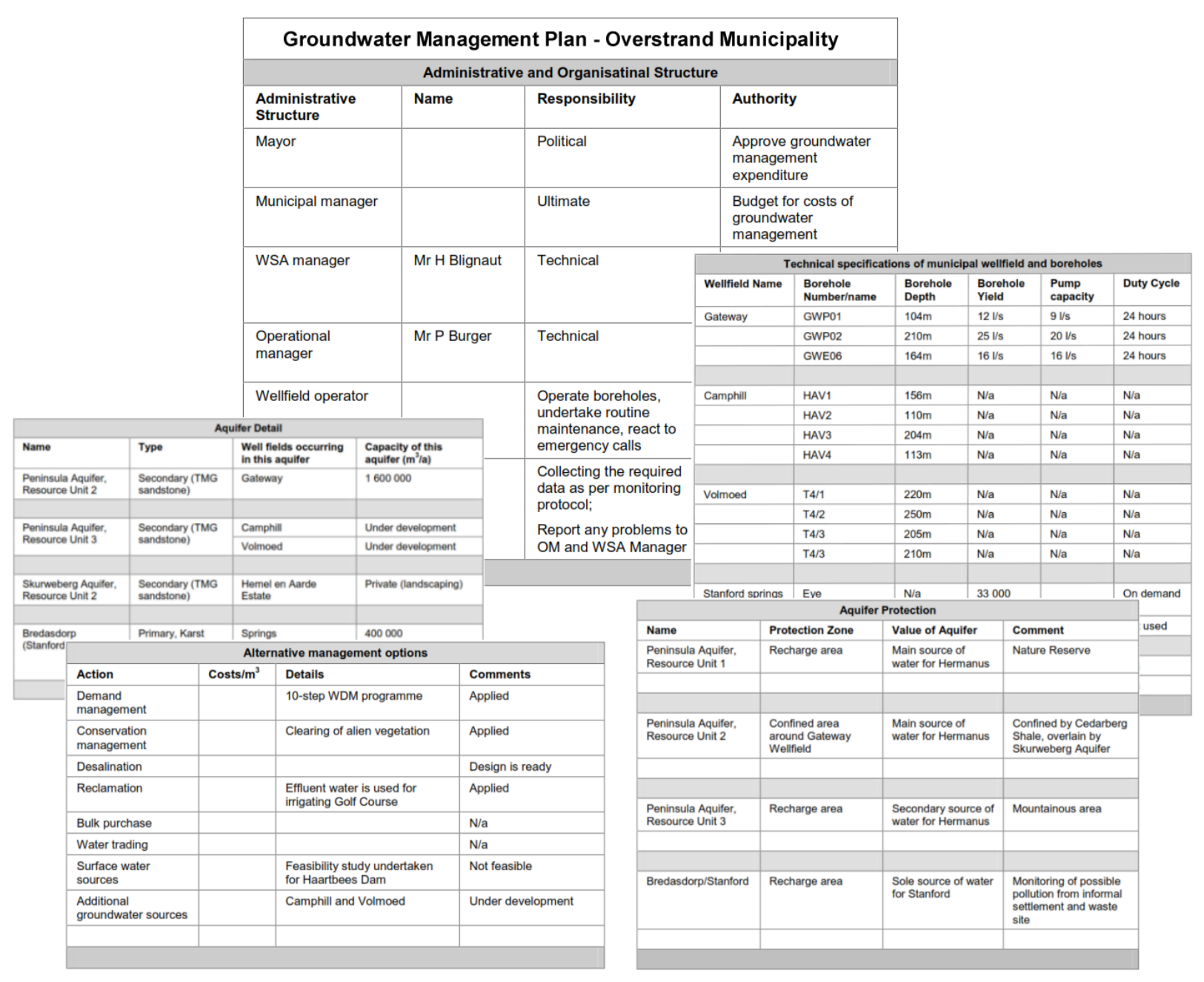

Figure 5

Examples from the Groundwater Management Plan of the Overstrand Municipality

Municipality for the groundwater supply to Hermanus (targeting the Peninsula Aquifer of the Table Mountain Group) and the supply for Stanford (from the quaternary sands and limestones of the Bredasdorp Group). The Overstrand Municipality falls within the Breede Water Management Area (WMA) and is part of the Overberg District Municipality. The Overstrand Municipality is the Water Services Authority (WSA), responsible for the provision of water to all people within its area of jurisdiction.

The Overstrand Municipality was chosen for this project, as it has separated the WSA and WSP functions within the municipal structures; this is the preferred structure to comply with relevant legislation, i.e. the WSP should not supervise and police itself. This structure enables a clear tracking of roles and responsibilities, as well as required skills for the various functions.

- The WSA functions are the responsibility of the water services manager within the Directorate: Infrastructure and Planning

- The WSP functions are the responsibility of the operations managers within the Directorate: Community Services

Several aspects of groundwater management have already been implemented by the Overstrand Municipality on an ongoing basis from 2002 onwards. These were consolidated and structured into the various categories by implementing the Framework. Some of the aspects are, for example:

- The SDF and Growth Management Strategy take recharge areas and aquifer vulnerability into account, as further developments are restricted in the recharge areas. Possible pollution sources, such as pit latrines, old waste sites, etc., are mapped and monitored.

- Municipal by-laws allow for registering and controlling of boreholes and water use.

- Detailed groundwater assessments were carried out for the current and future well-fields.

- Development of a Well-Field O\&M Manual and Well-Field Managers Guide for the Gateway Well-Field in Hermanus with a licensed abstraction capacity of $1.6 \times 10^{6} \mathrm{~m}^{3} / \mathrm{a}$.

- Establishment and regular meetings of the Onrus Monitoring Committee (OMC) as a subcommittee of the Onrus WUA to oversee the monitoring of the groundwater development. The OMC comprises representatives of the municipality, WUA, Ratepayers' Association, Cape Nature, Fernkloof Advisory Board, DWA, CMA, Onrus Lagoon Trust and other interested individuals.

Based on these interventions and actions and the aquifer characteristics, a Groundwater Management Plan was derived for Hermanus comprising the aquifer details, technical specifications of well-fields, aquifer-protection measures, alternative management options, and administrative/legal aspects. Excerpts of the Overstrand Groundwater Management Plan are shown in Fig. 5. 


\section{Conclusions}

The Groundwater Management Framework, proposed in this paper and outlined in Riemann et al. (2010), is an overarching guideline that brings together the various guidelines for groundwater management and fills the gaps identified in these guidelines.

The main elements of the Framework are:

- Definition and grouping of all aspects of groundwater management, including aquifer protection, well-field development, O\&M and monitoring

- Linking the aspects of groundwater management to the legal framework of the National Water Act (Act No. 36 of 1998) and the Water Services Act (Act No. 108 of 1997)

- Definition of management functions with respect to groundwater management

- Roles and responsibilities of local government officials for the different aspects of groundwater management

- Detailing of the complete monitoring cycle and feedback cycle for sustainable groundwater management

- Development of a framework and methodology to establish the value of the groundwater resource

- Outline and example of a groundwater management plan.

The trial implementation of the Framework within the Overstrand Municipality for the case studies of Hermanus and Stanford showed that the split between WSA and WSP function within the municipality supports the responsibilities for groundwater management, especially if both functions are involved in the well-field planning.

\section{Recommendations}

The Framework has proven to be of high significance for local government to gain an understanding of their responsibilities and required actions in groundwater management. Hence, it is of utmost importance that municipalities are introduced to this Framework and that the relevant officials are trained in using the guidelines to achieve sustainable groundwater management. Furthermore, it is strongly suggested that the Department of Water Affairs adopt this Framework as an overarching guideline and incorporate the suite of existing guidelines into this framework.

The following future work is recommended to support the above suggestions and to achieve a successful implementation of the Framework:

- Roll-out of Framework to local government

- Training of municipal officials in elements of the Framework and guidelines

- Update the DWA Guideline for Assessment and Management to incorporate details of the levels of assessment and planning

- Develop a guideline for monitoring data handling, including processing, quality control, storage and sharing of data
- Develop a guideline for adaptive management (monitor model - manage)

- Refine valuation methodology to include ecosystems and aquifer characteristics

\section{Acknowledgements}

The authors acknowledge with thanks the financial support of the Water Research Commission of South Africa and the contribution of the Project Reference Group throughout the study.

\section{References}

BARRETT R (2003) Vocational Business: Training, Developing and Motivating People. Nelson Thornes, Cheltenham.

DWAF (DEPARTMENT OF WATER AFFAIRS AND FORESTRY, SOUTH AFRICA) (2004a) Guidelines for Groundwater Resource Management in Water Management Areas, South Africa: Integrated Water Resource Management Strategies, Guidelines and Pilot Implementation in Three Water Management Areas, South Africa. Produced under The DANIDA Assisted Programme. Department of Water Affairs and Forestry, Pretoria, South Africa.

DWAF (DEPARTMENT OF WATER AFFAIRS AND FORESTRY, SOUTH AFRICA) (2004b) A Framework for Groundwater Management of Community Water Supply. Produced under: The NORAD-Assisted Programme for the Sustainable Development of Groundwater Sources under the Community Water and Sanitation Programme in South Africa. Department of Water Affairs and Forestry, Pretoria, South Africa.

DWAF (DEPARTMENT OF WATER AFFAIRS AND FORESTRY, SOUTH AFRICA) (2004c) National Water Resource Strategy ( $1^{\text {st }}$ edn.). Department of Water Affairs and Forestry, Pretoria, South Africa.

DWAF (DEPARTMENT OF WATER AFFAIRS AND FORESTRY, SOUTH AFRICA) (2007a) Framework for a National Groundwater Strategy. Department of Water Affairs and Forestry, Pretoria, South Africa.

DWAF (DEPARTMENT OF WATER AFFAIRS AND FORESTRY, SOUTH AFRICA) (2007b) Guidelines for Catchment Management Strategies towards Equity, Sustainability and Efficiency. Department of Water Affairs and Forestry, Pretoria, South Africa.

DWAF (DWAF (DEPARTMENT OF WATER AFFAIRS AND FORESTRY, SOUTH AFRICA) (2008) A Guideline for the Assessment, Planning and Management of Groundwater Resources in South Africa ( $1^{\text {st }}$ edn.). Department of Water Affairs and Forestry, Pretoria, South Africa.

MEYER R (2002) Guidelines for the Monitoring and Management of Ground Water Resources in Rural Water Supply Schemes. WRC Report No. 861/1/02a. Water Research Commission, Pretoria, South Africa.

RSA (REPUBLIC OF SOUTH AFRICA) (1997) South African Water Services Act, Act No. 108 of 1997. Government Gazette Volume 390. Cape Town.

RSA (REPUBLIC OF SOUTH AFRICA) (1998) South African National Water Act, Act No. 36 of 1998. Government Gazette Volume 398. Cape Town.

RIEMANN K, D LOUW, N CHIMBOZA and M FUBESI (2011) Groundwater Management Framework. WRC Report No. 1917/1/10. Water Research Commission, Pretoria, South Africa. 